\title{
Analisis pengaruh pendapatan perkapita dan belanja modal terhadap tingkat kemiskinan di Pulau Sumatera
}

\author{
Wenny Tri Septiani* ; Zamzami ; Candra Mustika
}

\author{
Prodi Ekonomi Pembangunan Fak. Ekonomi dan Binsis Universitas Jambi \\ *E-mail korespodensi : wenytriseptiani19@gmail.com
}

\begin{abstract}
This study aims to: 1) To analyze and determine the development of per capita income, capital expenditure, and poverty levels on the island of Sumatra. 2) To analyze and determine the effect of per capita income and capital expenditure on poverty levels in Sumatra Island. The research analysis tool used panel data regression analysis tools. Based on the results of panel data regression, it can be concluded that per capita income and capital expenditure on the poverty level together have a significant effect. Whereas partially only the per capita income variable had a significant and negative effect on the poverty level, while capital expenditure had no significant and positive effect on the poverty level.
\end{abstract}

Keywords: Poverty rate, Per capita income, Capital expenditures

\begin{abstract}
Abstrak
Penelitian ini bertujuan untuk: 1) Untuk menganalisis dan mengetahui perkembangan pendapatan perkapita, belanja modal dan tingkat kemiskinan di Pulau Sumatera. 2) Untuk menganalisis dan mengetahui pengaruh pendapatan perkapita dan belanja modal terhadap tingkat kemiskinan di Pulau Sumatera. Alat analisis penelitian menggunakan alat analisis regresi data panel. Berdasarkan hasil regresi data panel dapat disimpulkan bahwa pendapatan perkapita dan belanja modal terhadap tingkat kemiskinan secara bersama-sama berpengaruh signifikan. Sedangkan secara parsial hanya variabel pendapatan perkapita yang berpengaruh signfikan dan negatif terhadap tingkat kemiskinan, sementara belanja modal tidak berpengaruh signifikan dan positif terhadap tingkat kemiskinan.
\end{abstract}

Kata kunci: Tingkat kemiskinan, pendapatan perkapita dan belanja modal

\section{PENDAHULUAN}

Masalah kemiskinan menjadi hal yang sangat serius dan menjadi masalah bagi daerah yang kondisi perekonomiannya tertinggal jauh. Dimana strategi pembangunan yang hanya berorientasi pada pertumbuhan ekonomi yang menimbulkan suatu realita yakni kemiskinan yang tampak jelas. Seiring pertumbuhan ekonomi serta kesejahteraan rakyat yang hanya mengandalkan kemampuan fisik dan pola fikir yang menjadikan masyarakat tidak memiliki pandangan yang dapat mendorong peningkatan terhadap ekonomi melalui "human capital", dan tidak dapat diingkari bahwa pada kenyataannya siapapun yang terjebak dalam kemiskinan akan sangat sulit mengejar ketertinggalan.

Persebaran penduduk miskin di Indonesia juga tersebar secara tidak merata di seluruh wilayah Indonesia. Dalam lingkup yang lebih kecil bila dilihat per pulau, 
persentase penduduk miskin antar pulau tidak sama atau masih terdapat disparitas antar wilayah. Persentase penduduk miskin terbesar yaitu di Pulau Papua dan Maluku sebesar 21,99 persen di tahun 2017. Sementara persentase penduduk miskin terkecil yaitu Pulau Kalimantan sebesar 6,18 persen di tahun 2017. Sebaran penduduk miskin di Indonesia juga tidak merata antara pedesaan dan perkotaan dengan jumlah terbesar di wilayah pedesaan. Pulau Sumatera merupakan salah satu pulau di Indonesia dengan persentase jumlah penduduk miskin tertinggi yaitu sebesar 11,03 persen.

Tingginya kemiskinan di Pulau Sumatera menunjukkan kondisi makro yang buruk pada provinsi-provinsi di Pulau Sumatera. Kondisi makro yang buruk tersebut disebabkan oleh beberapa faktor, salah satunya adalah infrastuktur daerah dan keuangan daerah.

Dalam mendukung percepatan pengurangan kemiskinan diperlukan pembangunan sarana dan prasarana infrastruktur, untuk itu diperlukan campur tangan pemerintah disamping terbukanya peluang bagi pihak swasta. Syaiful (2008) mengutarakan bahwa pendapatan perkapita adalah pengeluaran yang dilakukan dalam rangka pembentukan modal yang sifatnya menambah aset tetap / inventaris yang memberikan manfaat lebih dari satu periode akuntansi, termasuk didalamnya adalah pengeluaran untuk biaya pemeliharaan yang sifatnya mempertahankan atau menambah masa manfaat, meningkatkan kapasitas dan kualitas aset. Pendapatan perkapita akan menghasilkan penyediaan sarana dan prasarana infrastruktur yang dibutuhkan oleh suatu daerah. Untuk mengetahui seberapa besar peranan pemerintah di dalam menyediakan sarana infrastruktur dapat dilihat dalam realisasi pendapatan perkapita dalam APBD masingmasing provinsi pada tahun yang bersangkutan. Semakin besar nilai pendapatan perkapita, maka semakin besar pula peran pemerintah di dalam melaksanakan pembangunan, begitu juga sebaliknya.

Selain belanja modal, dari sisi pendapatan perkapita juga dapat mempengaruhi pengurangan kemiskinan. Sukirno (2004) menyatakan bahwa efek buruk berkurangnya tingkat pendapatan masyarakat yaitu mengurangi tingkat kemakmuran/kesejahteraan. Berkurangnya tingkat pendapatan masyarakat yang dimaksud adalah pada pendapatan perkapita. Kesejahteraan masyarakat yang turun karena menganggur akan meningkatkan peluang mereka terjebak dalam kemiskinan karena tidak memiliki pendapatan.

Tabel 1. Pendapatan perkapita di Provinsi se-Sumatera tahun 2010-2017 (Ribuan rupiah)

\begin{tabular}{rlllllllll}
\hline \multirow{2}{*}{ No } & \multicolumn{1}{c}{ Provinsi } & \multicolumn{7}{c}{ Tahun } \\
\cline { 3 - 9 } & $\mathbf{2 0 1 0}$ & $\mathbf{2 0 1 1}$ & $\mathbf{2 0 1 2}$ & $\mathbf{2 0 1 3}$ & $\mathbf{2 0 1 4}$ & $\mathbf{2 0 1 5}$ & $\mathbf{2 0 1 6}$ & $\mathbf{2 0 1 7}$ \\
\hline 1 & Aceh & 22.450 & 23.429 & 24.295 & 25.219 & 26.065 & 25.786 & 26.937 & 27.732 \\
2 & Sumatera Utara & 25.412 & 28.518 & 31.109 & 34.544 & 37.914 & 41.020 & 44.558 & 47.475 \\
3 & Sumatera Barat & 21.585 & 24.057 & 26.286 & 28.994 & 32.141 & 34.526 & 37.205 & 39.778 \\
4 & Riau & 69.701 & 84.811 & 94.996 & 100.69 & 109.785 & 102.790 & 104.961 & 107.132 \\
5 & Jambi & 29.160 & 32.682 & 35.658 & 39.554 & 43.300 & 45.592 & 49.643 & 52.929 \\
6 & Sumatera Selatan & 25.932 & 29.830 & 32.830 & 35.810 & 38.585 & 41.341 & 43.551 & 47.073 \\
7 & Bengkulu & 16.464 & 18.369 & 20.299 & 22.358 & 24.604 & 26.847 & 29.086 & 31.022 \\
8 & Lampung & 19.722 & 21.981 & 23.911 & 25.769 & 28.755 & 31.196 & 34.261 & 36.069 \\
& Kepulauan & 28.907 & 32.465 & 35.288 & 38.315 & 41.948 & 44.429 & 46.457 & 50.150 \\
& Bangka Belitung & & & & & & & & \\
10 & Kepulauan Riau & 65.703 & 72.572 & 80.240 & 87.710 & 94.335 & 101.132 & 106.786 & 114.706 \\
\hline
\end{tabular}

Sumber : BPS, 2019(diolah) 
Dapat kita lihat pada Tabel 1. mengenai pendapatan perkapita di Provinsi seSumatera selama tahun 2010 sampai tahun 2017 dimana terdapat beberapa tahun pendapatan perkapitanya mengalami fluktuatif.

Tabel 2. Kontribusi belanja modal terhadap belanja daerah di Provinsi-Provinsi Pulau Sumatera tahun 2017

\begin{tabular}{clrcc}
\hline No & \multicolumn{1}{c}{ Daerah } & $\begin{array}{c}\text { Belanja modal } \\
\text { (Rp. milyar) }\end{array}$ & $\begin{array}{c}\text { Belanja daerah } \\
\text { (Rp. milyar) }\end{array}$ & $\begin{array}{c}\text { Kontribusi } \\
(\%)\end{array}$ \\
\hline 1 & Prov. Aceh & 2.284 & 12.119 & 18,85 \\
2 & Prov. Sumatera Utara & 1.019 & 9.476 & 10,75 \\
3 & Prov. Sumatera Barat & 989 & 4.504 & 21,96 \\
4 & Prov. Riau & 2.035 & 8.731 & 23,31 \\
5 & Prov. Jambi & 945 & 3.294 & 28,69 \\
6 & Prov. Sumatera Selatan & 607 & 4.962 & 12,23 \\
7 & Prov. Bengkulu & 385 & 2.029 & 18,97 \\
8 & Prov. Lampung & 1.005 & 5.476 & 18,35 \\
9 & Prov. Bangka Belitung & 229 & 2.069 & 11,07 \\
10 & Prov. Kepulauan Riau & 303 & 2.865 & 10,58 \\
\hline
\end{tabular}

Sumber : Direktorat jenderal perimbangan keuangan,2018 (diolah)

Dapat dilihat pada Tabel 2, besaran kontribusi belanja modal setiap wilayah di Pulau Sumatera tahun 2017 bervariasi. Kontribusi belanja modal terhadap belanja daerah yang terbesar terjadi di Provinsi Jambi yaitu sebesar 28,69 persen, sementara kontribusi terendah terjadi pada Provinsi Kepulauan Riau yaitu sebesar 10,58 persen. Besaran realisasi belanja modal tersebut mempunyai dampak terhadap kondisi makro di Pulau Sumatera.

Dari fenomena tersebut dapat dilihat bahwa buruknya kondisi makro di wilayah Pulau Sumatera dibuktikan dengan tingginya tingkat kemiskinan. Sementara pendapatan perkapita masih berfluktuasi dan belanja modal bila dilihat dari kontribusinya terhadap belanja daerah juga tidak besar. Untuk itu peneliti ingin mengetahui lebih lanjut pengaruh pendapatan perkapita dan belanja modal terhadap tingkat kemiskinan pada provinsiprovinsi di Pulau Sumatera dalam bentuk skripsi yang berjudul: "Analisis pengaruh pendapatan perkapita dan belanja modal terhadap tingkat kemiskinan di Pulau Sumatera".

\section{METODE}

\section{Jenis penelitian}

Menurut peneliti, penelitian ini menggunakan pendekatan deskriptif kuantitatif, dan jenis penelitian yang digunakan adalah kepustakaan (library research), yaitu mengumpulkan data atau karya tulis ilmiah yang berkaitan dengan obyek penelitian atau pengumulan data yang bersifat kepustakaan. Atau telaah yang dilaksanakan untuk memecahkan suatu masalah yang pada dasarnya tertumpu pada penelaahan kritis dan mendalam terhadap bahan- bahan pustaka yang relevan.

\section{Jenis data}

Data yang digunakan dalam penelitian ini adalah data sekunder berupa data deret waktu (time series data) selama kurun waktu tahun 2010-2017 dan data deret lintang 
(cross section data) yang meliputi 10 Provinsi di Pulau Sumatera. Data yang digunakan dalam penelitian ini diantaranya: 1). Tingkat kemiskinan Provinsi di Pulau Sumatera periode 2010 - 2017, 2).Realisasi pendapatan perkapita Provinsi di Pulau Sumatera periode 2010 - 2017, 3).Realisasi belanja modal Provinsi di Pulau Sumatera periode $2010-2017$.

\section{Sumber data}

Data yang digunakan dalam penelitian ini, dikumpulkan dari publikasi dan informasi data serta laporan-laporan yang dilakukan oleh dinas dan instansi terkait. Untuk memperoleh landasan teori, studi sebelumnya dan kerangka pemikiran dilakukan studi kepustakaan berupa buku-buku literatur.

Sumber data yang digunakan dalam penelitian ini berasal dari: 1). Badan Pusat Statistik (BPS), 2).Direktorat jenderal perimbangan keuangan

\section{Metode analisis data}

Metode analisis dalam penelitian ini adalah metode deskriptif dengan pendekatan kualitatif dan kuantitatif. Analisis kualitatif digunakan untuk menggambarkan dan menguraikan keadaan persoalan yang didukung oleh fakta, sifat-sifat serta hubungan antara fenomena yang dianalisis, sementara analisis kuantitatif digunakan untuk mengolah data menggunakan regresi berganda data panel.

\section{Analisis deskiptif}

Dalam menjawab permasalahan pertama maka digunakan analisis deskriptif digunakan merupakan suatu alat yang digunakan untuk mengetahui dan menganalisa perkembangan variabel yang digunakan dalam penelitian. Untuk menghitung besarnya perkembangan diketahui dengan menggunakan rumus berikut :

$$
G x=\frac{G x_{1}-G x_{t-1}}{G x_{t-1}} \times 100 \%
$$

Dimana :

Gx : Perkembangan variabel pendapatan perkapita dan belanja modal pertahun

$\mathrm{Gx}_{1}$ : Perkembangan tahun yang bersangkutan

$\mathrm{Gx}_{\mathrm{t}-1} \quad$ : Perkembangan tahun sebelumnya

\section{Analisis regresi data panel}

Menurut Nachrowi dan Usman (2006) bahwa data panel merupakan gabungan antara data berkala (time series) dan data individual (cross section). Data time series adalah data yang dikumpulkan dari waktu ke waktu terhadap suatu individu. Sedangkan data cross section merupakan data yang dikumpulkan dalam satu waktu terhadap banyak individu.

Keunggulan regresi data panel menurut Wibisono (2005) antara lain : Pertama. Panel data mampu memperhitungkan heterogenitas individu secara ekspilisit dengan mengizinkan variabel spesifik individu; kedua. Kemampuan mengontrol heterogenitas ini selanjutnya menjadikan data panel dapat digunakan untuk menguji dan membangun model perilaku lebih kompleks; Ketiga, data panel mendasarkan diri pada observasi cross-section yang berulang-ulang (time series), sehingga metode datapanel cocok digunakan sebagai study of dynamic adjustment; Keempat, tingginya jumlah observasi 
memiliki implikasi pada data yang lebih informative, lebih variatif, dan kolinieritas (multiko) antara data semakin berkurang, dan derajat kebebasan (degree of freedom/df) lebih tinggi sehingga dapat diperoleh hasil estimasi yang lebih efisien; Kelima, data panel dapat digunakan untuk mempelajari model-model perilaku yang kompleks; Keenam, Data panel dapat digunakan untuk meminimalkan bias yang mungkin ditimbulkan oleh agregasi data individu.

Permodelan dengan menggunakan teknik regresi data panel dapat dilakukan dengan tiga pendekatan alternatif metode pengolahannya yaitu, metode Common Effect (pooled least square), metode Fixed Effect (FE), dan metode Random Effect (RE).

Metode Common Effect adalah metode yang hanya menggabungkan data tanpa melihat perbedaan antar waktu dan individu, diasumsikan bahwa perilaku data antar kabupaten/kota sama dalam berbagai kurun waktu (Sugiyono, 2013). Dalam pendekatan ini tidak memperhatikan dimensi individu maupun waktu, dan dapat diasumsikan bahwa perilaku data antar perusahaan sama dalam berbagai rentang waktu. Asumsi ini jelas sangat jauh dari realita sebenarnya, karena karakteristik antar perusahaan baik dari segi kewilayahan jelas sangat berbeda.

Metode Fixed Effect adalah metode yang mengestimasi data panel dengan menggunakan variabel dummy untuk menangkap adanya perbedaan intersep. Metode ini mengasumsikan bahwa koefisien regresi (slope) tetap antar individu dan antar waktu. (Widarjono, 2006). Namun intersepnya berbeda antar perusahaan namun sama antar waktu (time invariant). Akan tetapi metode ini membawa kelemahan yaitu berkurangnya derajat kebebasan (degree of freedom) yang pada akhirnya mengurangi efisiensi parameter.

Metode Random Effect adalah metode yang akan mengestimasi data panel di mana variabel gangguan mungkin saling berhubungan antar waktu dan antar individu. (Sulistyaningsih, 2011). Tenik yang digunakan dalam Metode Random Effect adalah dengan menambahkan variabel gangguan (error terms) yang mungkin saja akan muncul pada hubungan antar waktu dan antar kabupaten/kota. Teknik metode OLS tidak dapat digunakan untuk mendapatkan estimator yang efisien, sehingga lebih tepat untuk menggunakan Metode Generalized Least Square (GLS).

Untuk menguji permodelan regresi data panel ketiga estimasi model regresi dengan melakukan Uji Chow dan Uji Hausman yang ditujukan untuk menentukan apakah model data panel dapat diregresi dengan metode Common Effect, metode Fixed Effect, atau metode Random Effect. (Husein ,2008).

Dalam penelitian ini variabel independen adalah PAD dan pendapatan perkapita sedangkan variabel dependen adalah tingkat kemiskinan. Adapun model regresi data panel sebagai berikut:

Dimana :

$$
T K_{i t}=\beta_{0}+\beta_{1} \log P P_{i t}+\beta_{2} \log B M_{i t}+e_{i t}
$$

$\beta_{0} \quad=$ Intersep,

$\beta_{1}$ dan $\beta_{2}=$ Parameter yang diduga dan menggambarkan hubungan variabel independent dengan variabel dependent,

$e_{i t} \quad=$ Error term,

$T K_{i t} \quad=$ Tingkat kemiskinan pada provinsi i periode $\mathrm{t}$,

$P P_{i t} \quad=$ Pendapatan perkapita pada provinsi i periode $\mathrm{t}$,

$B M_{i t} \quad=$ Belanja modal pada provinsi i periode $\mathrm{t}$, 


$\begin{array}{ll}\log & =\text { Logaritma } \\ i & =\text { Provinsi di Pulau Sumatera } \\ t & =\text { Tahun 2010-2017 }\end{array}$

\section{HASIL DAN PEMBAHASAN}

\section{Perkembangan pendapatan perkapita di Pulau Sumatera}

Pendapatan perkapita adalah besarnya pendapatan rata-rata penduduk disuatu negara atau daerah. Berikut dapat dilihat data pendapatan perkapita masing-masing provinsi di Sumatera selama tahun 2010 sampai tahun 2017 pada tabel berikut ini :

Tabel 3. Perkembangan pendapatan perkapita se-Sumatera tahun 2010-2017 (Ribu)

\begin{tabular}{|c|c|c|c|c|c|c|c|c|c|c|}
\hline \multirow{2}{*}{ No. } & \multirow{2}{*}{ Provinsi } & \multicolumn{8}{|c|}{ Tahun } & \multirow{2}{*}{$\begin{array}{l}\text { Rata- } \\
\text { Rata }\end{array}$} \\
\hline & & 2010 & 2011 & 2012 & 2013 & 2014 & 2015 & 2016 & 2017 & \\
\hline \multirow{2}{*}{1} & Aceh & 22.450 & 23.429 & 24.295 & 25.219 & 26.065 & 25.786 & 26.937 & 27.732 & 25.638 \\
\hline & Perkembangan (\%) & - & 4,36 & 3,70 & 3,80 & 3,35 & $-1,07$ & 4,46 & 2,95 & 3,08 \\
\hline \multirow{2}{*}{2} & Sumatera Utara & 25.412 & 28.518 & 31.109 & 34.544 & 37.914 & 41.020 & 44.558 & 47.475 & 37.877 \\
\hline & Perkembangan $(\%)$ & - & 12,22 & 9,09 & 11,04 & 9,76 & 8,19 & 8,63 & 6,55 & $\mathbf{9 , 3 5}$ \\
\hline \multirow{2}{*}{3} & Sumatera Barat & 21.585 & 24.057 & 26.286 & 28.994 & 32.141 & 34.526 & 37.205 & 39.778 & 31.855 \\
\hline & Perkembangan (\%) & - & 11,45 & 9,27 & 10,30 & 10,85 & 7,42 & 7,76 & 6,92 & 9,14 \\
\hline \multirow{2}{*}{4} & Riau & 69.701 & 84.811 & 94.996 & 100.691 & 109.785 & 102.790 & 104.961 & 117.752 & 102.225 \\
\hline & Perkembangan (\%) & - & 21,68 & 12,01 & 5,99 & 9,03 & $-6,37$ & 2,11 & 12,19 & 8,09 \\
\hline \multirow{2}{*}{5} & Jambi & 29.160 & 32.682 & 35.658 & 39.554 & 43.300 & 45.592 & 49.643 & 52.929 & 42.765 \\
\hline & Perkembangan (\%) & - & 12,08 & 9,11 & 10,93 & 9,47 & 5,29 & 8,89 & 6,62 & 8,91 \\
\hline \multirow{2}{*}{6} & Sumatera Selatan & 25.932 & 29.830 & 32.830 & 35.810 & 38.585 & 41.341 & 43.551 & 47.073 & 38.431 \\
\hline & Perkembangan (\%) & - & 15,03 & 10,06 & 9,08 & 7,75 & 7,14 & 5,35 & 8,09 & 8,93 \\
\hline \multirow{2}{*}{7} & Bengkulu & 16.464 & 18.369 & 20.299 & 22.358 & 24.604 & 26.847 & 29.086 & 31.022 & 24.655 \\
\hline & Perkembangan (\%) & - & 11,57 & 10,51 & 10,14 & 10,05 & 9,12 & 8,34 & 6,66 & 9,48 \\
\hline \multirow{2}{*}{8} & Lampung & 19.722 & 21.981 & 23.911 & 25.769 & 28.755 & 31.196 & 34.261 & 36.069 & 28.384 \\
\hline & Perkembangan $(\%)$ & - & 11,45 & 8,78 & 7,77 & 11,59 & 8,49 & 9,82 & 5,28 & 9,03 \\
\hline \multirow[t]{2}{*}{9} & $\begin{array}{l}\text { Kepulauan Bangka } \\
\text { Belitung }\end{array}$ & 28.907 & 32.465 & 35.288 & 38.315 & 41.948 & 44.429 & 46.457 & 50.150 & 41.293 \\
\hline & Perkembangan (\%) & - & 12,31 & 8,70 & 8,58 & 9,48 & 5,91 & 4,56 & 7,95 & 8,21 \\
\hline \multirow{2}{*}{10} & Kepulauan Riau & 65.703 & 72.572 & 80.240 & 87.710 & 94.335 & 101.132 & 106.786 & 114.706 & 93.926 \\
\hline & Perkembangan $(\%)$ & - & 10,45 & 10,57 & 9,31 & 7,55 & 7,21 & 5,59 & 7,42 & 8,30 \\
\hline
\end{tabular}

Sumber : www.bps.go.id (Data diolah)

Dapat dilihat pada Tabel 3 mengenai pendapatan perkapita di Provinsi seSumatera selama tahun 2010 sampai tahun 2017 dimana terdapat beberapa tahun pendapatan perkapitanya mengalami fluktuatif. Untuk rata-rata pendapatan perkapita tertinggi terjadi pada Provinsi Riau dengan rata-rata pendapatan perkapita selama tujuh tahun terakhir sebesar Rp. 102.225 ribu. Sedangkan rata-rata pendapatan perkapita terendah terjadi pada Provinsi Bengkulu dengan pendapatan perkapita selama tujuh tahun terakhir sebesar Rp.24.665 ribu, artinya rata-rata pendapatan penduduk di Provinsi Bengkulu hanya sebesar Rp.24.655 ribu.

Berdasarkan rata-rata pendapatan perkapita di Provinsi se-Sumatera dapat kita simpulkan terdapat kesenjangan pendapatan perkapita antar provinsi yang ada di Sumatera. Hal ini dikarenakan perbedaan jumlah penduduk dan PDRB atas dasar harga konstan pada masing-masing provinsi di Sumatera. Selanjutnya dapat dilihat pada tabel 
berikut perkembangan pendapatan perkapita di Provinsi se-Sumatera selama tahun 20102017.

Dapat dilihat pada tabel 3 perkembangan pendapatan perkapita di Provinsi seSumatera selama tahun 2010 sampai tahun 2017 dimana seluruh provinsi di Sumatera perkembangan pendapatan perkapitanya mengalami pertumbuhan yang berfluktuatif. Untuk rata-rata perkembangan pendapatan perkapita tertinggi terjadi pada Provinsi Bengkulu yaitu sebesar 9,48 persen dan perkembangan pendapatan perkapita tertinggi kedua terjadi pada Provinsi Sumatera Utara yaitu sebesar 9,35 persen. Sementara untuk rata-rata perkembangan pendapatan perkapita terendah terjadi pada Provinsi Aceh yaitu hanya sebesar 3,08 persen.

Seharusnya pemerintah provinsi-provinsi di Sumatera harus meningkatkan pendapatan perkapitanya dengan meningkatkan PDRB pada sektor-sektor unggulan didaerahnya masing-masing.

\section{Analisis belanja modal}

Belanja modal merupakan suatu pengeluaran yang dapat dikatakan sebagai pengeluaran rutin dalam rangka pembentukkan modal yang ada. Untuk kondisi belanja modal di Pulau Sumatera dapat kita lihat pada tabel berikut ini :

Tabel 4. Perkembangan belanja modal di Provinsi se-Sumatera tahun 2010-2017 (Persen)

\begin{tabular}{lrrccccccc}
\hline \multirow{2}{*}{ Provinsi } & \multicolumn{8}{c}{ Belanja Modal (Rp. Milyar) } & Rata- \\
\cline { 2 - 9 } & $\mathbf{2 0 1 0}$ & $\mathbf{2 0 1 1}$ & $\mathbf{2 0 1 2}$ & $\mathbf{2 0 1 3}$ & $\mathbf{2 0 1 4}$ & $\mathbf{2 0 1 5}$ & $\mathbf{2 0 1 6}$ & $\mathbf{2 0 1 7}$ & Rata \\
\hline Aceh & 3268 & 1474 & 815 & 1650 & 2398 & 2025 & 2582 & 2679 & 2111 \\
Perkembangan (\%) & $-11,6$ & $-54,9$ & $-44,7$ & 102,4 & 45,3 & $-15,5$ & 27,5 & 3,74 & 6,53 \\
Sumatera Utara & 717 & 1063 & 804 & 761 & 1146 & 932 & 1243 & 1542 & 1026 \\
Perkembangan (\%) & 1,8 & 48,3 & $-24,4$ & $-5,3$ & 50,6 & $-18,7$ & 33,4 & 24,02 & 13,72 \\
Sumatera Barat & 583 & 594 & 646 & 692 & 786 & 788 & 1164 & 1322 & 822 \\
Perkembangan (\%) & 26,2 & 1,9 & 8,6 & 7,1 & 13,7 & 0,3 & 47,7 & 13,56 & 14,88 \\
Riau & 1421 & 1342 & 1962 & 2245 & 624 & 2015 & 2532 & 2661 & 1850 \\
Perkembangan (\%) & 27 & $-5,6$ & 46,2 & 14,5 & $-72,2$ & 223 & 25,7 & 5,09 & 32,96 \\
Jambi & 466 & 519 & 679 & 938 & 818 & 791 & 1087 & 1284 & 823 \\
Perkembangan (\%) & 4,5 & 11,4 & 30,8 & 38,2 & $-12,8$ & $-3,3$ & 37,4 & 18,08 & 15,53 \\
Sumatera Selatan & 1033 & 1139 & 1017 & 863 & 732 & 1041 & 1242 & 1387 & 1057 \\
Perkembangan (\%) & 61,3 & 10,2 & $-10,7$ & $-15,2$ & $-15,2$ & 42,3 & 19,3 & 11,68 & 12,96 \\
Bengkulu & 165 & 221 & 290 & 277 & 305 & 479 & 589 & 612 & 367 \\
Perkembangan (\%) & $-33,7$ & 33,8 & 31,4 & $-4,4$ & 10 & 57,1 & 22,9 & 3,96 & 15,13 \\
Lampung & 426 & 631 & 832 & 804 & 926 & 869 & 1067 & 1128 & 835 \\
Perkembangan (\%) & 82,5 & 48,2 & 31,8 & $-3,3$ & 15,1 & $-6,1$ & 22,8 & 5,70 & 24,59 \\
Kepulauan Bangka & 313 & 488 & 291 & 403 & 306 & 234 & 341 & 374 & 344 \\
Belitung & 31,6 & 55,6 & $-40,4$ & 38,5 & $-24,1$ & $-23,5$ & 45,8 & 9,74 & 11,66 \\
Perkembangan (\%) & 652 & 260 & 262 & 393 & 718 & 341 & 408 & 521 & 444 \\
Kepulauan Riau & -10 & $-60,1$ & 0,9 & 49,8 & 82,7 & $-52,5$ & 19,5 & 27,70 & 7,25 \\
Perkembangan (\%) & &
\end{tabular}

Sumber : Badan pusat statistik nasional 2019

Berdasarkan tabel 4 dapat kita lihat bahwa realisasi belanja modal di provinsi seSumatera selama tahun 2010 sampai tahun 2017 mengalami perkembangan yang berfluktuasi. Untuk rata-rata perkembangan realisasi belanja modal terendah yaitu terjadi di Provinsi Kepulauan Riau selama tahun 2010-2017 hanya sebesar 7,25 persen, 
rendahnya perkembangan tersebut disebabkan tidak banyaknya kebutuhan anggaran untuk pembangunan infrastruktur dari tahun ke tahun. Sedangkan rata-rata perkembangan belanja modal tertinggi terjadi pada Provinsi Riau selama tahun 20102017 sebesar 32,96 persen. Hal ini disebabkan pemerintah Provinsi Riau sedang dalam pengembangan industri terpadu dan pembangunan jalan tol Pekanbaru-Pangkalan Kerinci.

Selanjutnya rata-rata realisasi belanja modal terbesar di Pulau Sumatera selama periode tahun 2010-2017 terjadi pada Provinsi Aceh yakni sebesar Rp. 2.111 milyar. Besarnya realisasi belanja modal dikarenakan banyaknya infrastruktur yang rusak seperti jalan dan jembatan yang disebabkan oleh bencana alam gempa dan tsunami pada tahun 2004, sehingga pemerintah Provinsi Aceh sangat membutuhkan anggaran belanja modal yang besar untuk membiayai pembangunan infrastrukturnya. Sementara rata-rata realisasi belanja modal terkecil terjadi pada Provinsi Kepulauan Bangka Belitung yakni hanya sebesar Rp.344 milyar setiap tahunnya. Rendahnya belanja modal tersebut disebabkan kurang maksimalnya pemerintah daerah Provinsi Kepulauan Bangka Belitung dalam merealisasikan anggaran belanja modal atau tidak tercapai nya target yang tealh ditetapkan.

\section{Analisis kemiskinan di Sumatera}

Kemiskinan dapat diukur dengan tingkat kemiskinan. Tingkat kemiskinan merupakan persentase kemiskinan dari total penduduk suatu daerah (Sumedi dan Supadi, 2004). Tingkat kemiskinan dapat dihitung dengan melihat proporsi jumlah penduduk miskin terhadap total penduduk di daerah tersebut.

Tabel 5 Perkembangan tingkat kemiskinan Provinsi Se-Sumatera, 2010-2017

\begin{tabular}{|c|c|c|c|c|c|c|c|c|c|c|}
\hline \multirow{2}{*}{ No } & \multirow{2}{*}{ Provinsi } & \multicolumn{8}{|c|}{ Tahun } & \multirow{2}{*}{$\begin{array}{l}\text { Rata- } \\
\text { Rata }\end{array}$} \\
\hline & & 2010 & 2011 & 2012 & 2013 & 2014 & 2015 & 2016 & 2017 & \\
\hline \multirow{2}{*}{1} & Aceh & 19,95 & 19,48 & 18,58 & 17,72 & 16,98 & 17,11 & 16,43 & 15,92 & 17,77 \\
\hline & Perkembangan $(\%)$ & - & $-2,36$ & $-4,62$ & $-4,63$ & $-4,18$ & 0,77 & $-3,97$ & $-3,10$ & $-3,16$ \\
\hline \multirow{2}{*}{2} & Sumatera Utara & 11,36 & 10,83 & 10,41 & 10,39 & 9,85 & 10,79 & 10,27 & 9,28 & 10,40 \\
\hline & Perkembangan (\%) & & $-4,67$ & $-3,88$ & $-0,19$ & $-5,2$ & 9,54 & $-4,82$ & $-9,64$ & $-2,69$ \\
\hline \multirow{2}{*}{3} & Sumatera Barat & 9,44 & 8,99 & 8 & 7,56 & 6,89 & 6,71 & 7,14 & 6,75 & 7,69 \\
\hline & Perkembangan $(\%)$ & - & $-4,77$ & $-11,01$ & $-5,5$ & $-8,86$ & $-2,61$ & 6,41 & $-5,46$ & $-4,54$ \\
\hline \multirow{2}{*}{4} & Riau & 10,01 & 8,17 & 8,05 & 8,42 & 7,99 & 8,82 & 7,67 & 7,41 & 8,32 \\
\hline & Perkembangan $(\%)$ & & $-18,4$ & $-1,47$ & 4,6 & $-5,11$ & 10,39 & $-13,0$ & $-3,39$ & $-3,77$ \\
\hline \multirow{2}{*}{5} & Jambi & 8,4 & 7,9 & 8,28 & 8,42 & 8,39 & 9,12 & 8,37 & 7,9 & 8,35 \\
\hline & Perkembangan $(\%)$ & - & $-5,95$ & 4,81 & 1,69 & $-0,36$ & 8,7 & $-8,22$ & $-5,62$ & $-0,71$ \\
\hline \multirow{2}{*}{6} & Sumatera Selatan & 14,8 & 13,95 & 13,48 & 14,06 & 13,62 & 13,77 & 13,39 & 13,1 & 13,77 \\
\hline & Perkembangan $(\%)$ & - & $-5,74$ & $-3,37$ & 4,3 & $-3,13$ & 1,1 & $-2,76$ & $-2,17$ & $-1,68$ \\
\hline \multirow{2}{*}{7} & Bengkulu & 16,37 & 17,36 & 17,51 & 17,75 & 17,09 & 17,16 & 17,03 & 15,59 & 16,98 \\
\hline & Perkembangan $(\%)$ & & 6,05 & 0,86 & 1,37 & $-3,72$ & 0,41 & $-0,76$ & $-8,46$ & $-0,61$ \\
\hline \multirow{2}{*}{8} & Lampung & 17,76 & 16,58 & 15,65 & 14,39 & 14,21 & 13,53 & 13,86 & 13,04 & 14,88 \\
\hline & Perkembangan $(\%)$ & - & $-6,64$ & $-5,61$ & $-8,05$ & $-1,25$ & $-4,79$ & 2,44 & $-5,92$ & $-4,26$ \\
\hline \multirow[t]{2}{*}{9} & $\begin{array}{l}\text { Kepulauan Bangka } \\
\text { Belitung }\end{array}$ & 7,51 & 5,16 & 5,37 & 5,25 & 4,97 & 4,83 & 5,04 & 5,3 & 5,43 \\
\hline & Perkembangan $(\%)$ & - & $-31,3$ & 4,07 & $-2,23$ & $-5,33$ & $-2,82$ & 4,35 & 5,16 & $-4,01$ \\
\hline \multirow{2}{*}{10} & Kepulauan Riau & 8,13 & 6,79 & 6,83 & 6,35 & 6,4 & 5,78 & 5,84 & 6,13 & 6,53 \\
\hline & Perkembangan $(\%)$ & - & $-16,5$ & 0,59 & $-7,03$ & 0,79 & $-9,69$ & 1,04 & 4,97 & $-3,69$ \\
\hline
\end{tabular}

Sumber : Badan pusat statistik nasional 2019 
Dapat dilihat pada tabel 5.3 yang menggambarkan kondisi kemiskinan di Provinsi se-Sumatera selama 7 tahun terakhir yaitu dari tahun 2010 sampai tahun 2017 dilihat tingkat kemiskinan. Jika dilihat dari angka dan perkembangan tingkat kemiskinan terdapat adanya perbedaan kondisi kemiskinan masing-masing Provinsi di Sumatera. Pada periode 2010-2017, rata-rata tingkat kemiskinan tertinggi terjadi pada Provinsi Aceh dengan rata-rata tingkat kemiskinan selama delapan tahun terakhir sebesar 17,77 persen, artinya proporsi penduduk miskin terhadap total penduduk di Provinsi Aceh sebesar 17,77 persen. Setelah membahas rata-rata tingkat kemiskinan tertinggi, maka selanjutnya akan dibahas rata-rata tingkat kemiskinan terendah pada Provinsi seSumatera. Pada periode tahun 2010-2017, rata-rata tingkat kemiskinan terendah terjadi pada Provinsi Kepulauan Bangka Belitung dengan tingkat kemiskinan selama delapan tahun terakhir hanya sebesar 5,43 persen, artinya proporsi penduduk miskin terhadap total penduduk di Provinsi Kepulauan Bangka Belitung sebesar 5,43 persen. Dapat dilihat juga pada tabel 5.3 perkembangan tingkat kemiskinan, di Provinsi se-Sumatera selama tahun 2010 sampai tahun 2017 dimana seluruh provinsi di Sumatera perkembangan tingkat kemiskinan mengalami pertumbuhan yang berfluktuatif. Untuk rata-rata penurunan tingkat kemiskinan tertinggi terjadi pada Provinsi Sumatera Barat yaitu sebesar $-4,54$ persen pertahunnya dan penurunan tingkat kemiskinan tertinggi kedua terjadi pada Provinsi Lampung yaitu sebesar $-4,26$ persen pertahunnya.

\section{Pengaruh pendapatan perkapita dan belanja modal terhadap tingkat kemiskinan}

Langkah pertama yaitu menentukan metode yang terbaik antara PLS, FEM atau REM dengan menggunakan Uji Chow. Chow Test (Uji Chow) Dilakukan untuk membandingkan/memilih model mana yang terbaik antara PLS dan FEM.

Tabel 6 Uji chow untuk memilih antara model PLS dengan FEM

\begin{tabular}{lcrc}
\hline Effects Test & Statistic & d.f. & Prob. \\
\hline Cross-section F & 272.980081 & $(9,58)$ & 0.0000 \\
Cross-section Chi-square & 263.865965 & 9 & 0.0000 \\
\hline Sumber: Data diolah, 2019 & & &
\end{tabular}

Berdasarkan output Eviews tersebut menunjukan bahwa baik $\mathrm{F}$ test maupun ChiSquare signifikan (Prob. 0,0000 dan 0,0000 lebih kecil dibandingkan alfa 0,05 persen), sehingga model ini hipotesis Ho ditolak dan H1 diterima. Dengan demikian, dapat disimpulkan bahwa model FEM lebih baik dibandingkan model PLS. Sehingga pengujian berikutnya yaitu dengan membandingkan metode FEM atau REM dengan melakukan uji hasuman. Hausman Test (Uji Hausman) dilakukan untuk membandingkan/memilih model mana yang terbaik antara FEM dan REM.

Tabel 7. Uji Hausman untk memilih antara model FEM dengan REM

Correlated Random Effects - Hausman Test

Pool: POOL01

\section{Test cross-section random effects}

Test Summary

Chi-Sq. Statistic Chi-Sq. d.f. Prob.

\begin{tabular}{llll} 
Cross-section random & 2.051322 & 2 & 0.3586 \\
\hline Sumber: Data diolah, 2019 & &
\end{tabular}

Berdasarkan output Eviews tersebut menunjukan bahwa nilai statistic Chi-Square memiliki Prob lebih besar dibadingkan alfa 0,05 persen $(0,3586>0,05)$, sehingga hipotesis $\mathrm{H}_{0}$ diterima dan $\mathrm{H}_{1}$ ditolak. Dengan demikian dapat disimpulkan bahwa model 
REM lebih baik dibandingkan FEM. Selanjutnya pengujian Uji Lagrange Multiplier untuk menentukan metode yang terbaik antara PLS dan REM. Uji Lagrange Multiplier dilakukan untuk membandingkan/memilih model mana yang terbaik antara PLS dan REM.

Tabel 8. Uji lagrange multiplier untuk memilih antara model PLS dengan REM Lagrange multiplier (LM) test for panel data

\begin{tabular}{lccc}
\hline $\begin{array}{l}\text { Null (no rand. effect) } \\
\text { Alternative }\end{array}$ & $\begin{array}{c}\text { Cross-section } \\
\text { One-sided }\end{array}$ & $\begin{array}{c}\text { Period } \\
\text { One-sided }\end{array}$ & Both \\
\hline Breusch-Pagan & 1.394862 & 73.18009 & 74.57495 \\
Honda & $(0.2376)$ & $(0.0000)$ & $(0.0000)$ \\
& -1.181043 & 8.554536 & 5.213847 \\
King-Wu & $(0.8812)$ & $(0.0000)$ & $(0.0000)$ \\
& -1.181043 & 8.554536 & 5.634716 \\
GHM & $(0.8812)$ & $(0.0000)$ & $(0.0000)$ \\
& -- & -- & 73.18009 \\
\hline
\end{tabular}

Adapun hipotesis yang digunakan dalam pemilihan uji lagrange multiplier ini adalah jika p-value $<\alpha$, maka $H_{0}$ ditolak dan $H_{1}$ diterima, artinya model REM lebih baik dibandingkan model PLS. Sedangkan apabila p-value $>\alpha$, maka $H_{1}$ ditolak dan $H_{0}$ diterima, artinya model PLS lebih baik dibandingkan model REM.

\section{Hasil pengujian estimasi model REM}

Hasil estimasi persamaan data panel tentang pengaruh pendapatan perkapita dan belanja modal terhadap tingkat kemiskinan adalah sebagai berikut :

Tabel 8. Hasil estimasi random effects model (REM)

\begin{tabular}{lrrrc}
\hline \multicolumn{1}{c}{ Variable } & Coefficient & Std. Error & t-Statistic & Prob. \\
\hline C & 13.20749 & 1.552949 & 8.504782 & 0.0000 \\
PP? & -0.001316 & 0.000208 & -6.337948 & 0.0000 \\
BM? & 0.000128 & 0.000259 & 0.496125 & 0.6214 \\
Random Effects (Cross) & & & & \\
_Aceh-C & 6.351049 & & & \\
Sumatera Utara--C & 2.583859 & & \\
_Sumatera Barat--C & -3.520707 & & \\
_Riau_C & -1.395695 & & \\
_Jambi-C & -3.475454 & & \\
_Sumatera Selatan--C & 3.258424 & & \\
_Bengkulu-C & 4.651022 & & \\
_Lampung-C & 4.230717 & & \\
_Kep Bangka Belitung--C & -7.144815 & & \\
_Kep Riau-C & -5.538400 & & \\
R-squared & 0.388311 & Mean dependent var & \\
Adjusted R-squared & 0.370052 & S.D. dependent var & \\
S.E. of regression & 0.698592 & Sum squared resid & 32.6980180 \\
F-statistic & 21.26643 & Durbin-Watson stat & 0.908323 \\
Prob(F-statistic) & 0.000000 & & \\
R-squared & -0.087001 & Mean dependent var & 11.14943 \\
Sum squared resid & 1474.220 & Durbin-Watson stat & 0.020147 \\
\hline
\end{tabular}

Sumber: Data diolah, 2019 
Dari hasil output Tabel 7 dapat dilihat bahwa nilai Prob. Breusch-Pagan (BP) sebesar 0,0000 (Pada kolom ketiga yaitu "Both"). Sesuai hipotesis, jika Prob BP $(0,0000)$ $<0,05$ maka H0 ditolak, dengan kata lain model yang cocok adalah Random Effect Model. Maka berdasarkan hasil pengujian tersebut dapat diketahui model yang digunakan dalam penelitian ini adalah Model Random Effect (REM).

\section{Uji hipotesis}

\section{Koefisien determinasi $\left(\mathbf{R}^{2}\right)$}

Dari hasil pengujian diperoleh koefisien determinasi $\left(\mathrm{R}^{2}\right)$ sebesar 0,3883 artinya sebesar 38,83 persen variasi tingkat kemiskinan dijelaskan oleh variabel bebas dalam model pendapatan perkapita dan belanja modal sedangkan sisanya 61,17 persen dijelaskan oleh variabel lain diluar peneitian.

\section{Uji F statistik}

Dapat dilihat pendapatan perkapitaa tabel 5.8 diatas diketahui juga bahwa nilai Prob (f Statistik) $0,0000<0,05$, maka berarti Ho ditolak dan menerima Ha, yang artinya uji secara bersama sama menunjukkan pendapatan perkapita dan belanja modal secara simultan berpengaruh signifikan terhadap tingkat kemiskinan.

\section{Uji t statistik}

Untuk menguji signifikasi pengaruh, pendapatan perkapita dan belanja modal terhadap tingkat kemiskinan secara parsial maka digunakan uji t statistik. Uji t Statistik berguna untuk melihat besarnya pengaruh masih-masing variabel Independen terhadap variabel dependen secara parsial. Tingkat kepercayaan 95 persen dengan uji dua arah dan df $=77(n=80-3)$ nilai $\mathrm{t}$ tabel yang diperoleh adalah 1,6679 digunakan alat uji t Statistik yang dapat di lihat di tabel berikut ini:

Tabel 9 Nilai $t$ statistik metode REM

\begin{tabular}{lcccc}
\hline \multicolumn{1}{c}{ Variabel } & t Hitung & t Tabel & Prob. & Keterangan \\
\hline Pendapatan Perkapita & $-6,3779$ & 1,6648 & 0,0000 & Signifikan \\
Belanja Modal & 0,4961 & 1,6648 & 0,6214 & Tidak Signfikan \\
\hline
\end{tabular}

Sumber: Data diolah, 2019

Berdasarkan Tabel 9 dapat diterangkan hasil uji t statistic dimana: 1).Diketahui bahwa nilai t hitung variabel pendapatan perkapita yaitu -6,3779. Jika dilihat dari Prob dari pendapatan perkapita sebesar 0,000 karena Prob $<0,05$ persen, maka $\mathrm{H}_{0}$ ditolak dan $\mathrm{H}_{\mathrm{a}}$ diterima. Ini menunjukkan bahwa pendapatan perkapita berpengaruh terhadap tingkat kemiskinan. 2).Diketahui bahwa nilai t hitung variabel belanja modal yaitu 0,4961 . Jika dilihat dari Prob dari belanja modal sebesar 0,6214 karena Prob $>0,05$ persen, maka $\mathrm{H}_{0}$ diterima dan menolak $\mathrm{H}_{a}$. Ini menunjukkan bahwa belanja modal tidak berpengaruh terhadap tingkat kemiskinan

Berdasarkan hasil estimasi pada Tabel 9 tersebut dapat diketahui penjelasan masing-masing variabel dalam penelitian yaitu pendapatan perkapita dan belanja modal terhadap tingkat kemiskinan dapat dijelaskan persamaan model sebagai berikut:

TK $_{\text {it }}=13,20749-0,001316 P P_{i t}+0,000128 B M_{i t}+e$ 
Prob $=\quad(0,0000) \quad(0,6214)$

Berdasarkan Persamaan Model diatas dapat dijelaskan hasil estimasi terhadap Random effect adalah jika terjadi perubahan antara pendapatan perkapita dan belanja modal baik antar wilayah maupun antar waktu, maka nilai konstanta sebesar 13,20749 Hal ini berarti apabila pendapatan perkapita dan belanja modal tetap/tidak berubah maka tingkat kemiskinan provinsi di Pulau Sumatera meningkat sebesar 13,20749 persen.

Nilai koefisien pendapatan perkapita sebesar -0,001316. Hal ini diartikan jika pendapatan perkapita meningkat seribu rupiah maka tingkat kemiskinan provinsi di Pulau Sumatera menurun sebesar $-0,001316$ persen. Nilai koefisien belanja modal sebesar 0,000128. Hal ini diartikan jika belanja modal meningkat satu milyar rupiah maka tingkat kemiskinan provinsi di Pulau Sumatera meningkat sebesar 0,000128 persen.

Berdasarkan hasil penelitian bahwa dapat dibuat analisis ekonomi yaitu diketahui bahwa pendapatan perkapita berpengaruh terhadap tingkat kemiskinan. Hasil ini sependapat dengan teori yang dikemukakan oleh Sukirno (2006) yang mengatakan bahwa pendapatan perkapita merupakan salah satu ukuran kemakmuran bagi tiap daerah. Semakin tinggi pendapatan tersebut maka semakin tinggi daya beli penduduk, dan daya beli yang bertambah ini akan meningkatkan kesejahteraan masyarakat.. Hasil ini sependapat dikarenakan pendapatan perkapita cenderung meningkat setiap tahunnya, meningkatnya pendapatan perkapita menunjukkan bahwa membaiknya perekonomian seluruh masyarakat termasuk penduduk miskin. Sehingga dengan meningkatnya pendapatan perkapita akan mengurangi tingkat kemiskinan. Selanjutnya iketahui bahwa belanja modal tidak berpengaruh terhadap tingkat kemiskinan. Hasil ini tidak sependapat dengan teori yang dikemukakan oleh Hasan dan Zikriah (2009) menyimpulkan bahwa peningkatan alokasi belanja modal memberi dampak positif terhadap penduduk miskin, karena ketersediaan infrastruktur yang memadai merupakan dampak positif dari peningkatan belanja modal pemerintah dan akan memudahkan masyarakat untuk melakukan aktivitas ekonomi maupun sosial kemasyarakatan, akan tetapi belanja modal belum dapat berpengaruh secara signfikan terhadap tingkat kemiskinan di ProvinsiProvinsi di Sumatera. Hal ini dibuktikan masih belum konsistennya peningkatan realisasi belanja modal selama tahun 2010-2017 sehingga belanja modal tidak berdampak besar terhadap pengurangan kemiskinan.

\section{Implikasi kebijakan}

Berdasarkan hasil penelitian bahwa dapat dibuat beberapa kebijakan untuk menurunkan tingkat kemiskinan yaitu untuk menurunkan jumlah penduduk miskin, maka perlu meningkatkan pendapatan perkapita. Salah satu hal yang dapat dilakukan adalah mengadakan program tepat sasaran yang menitik beratkan pada masyarakat miskin, misalnya dengan mengembangkan industri rumah tangga. Untuk mengembangkan industri rumah tangga tersebut melalui pelatihan pada setiap sektor produksi dengan potensi yang dimiliki pada tiap daerah. Dengan adanya pengolahan, maka akan menigkatkan harga jual serta manfaat yang lebih tinggi. Pemerintah harus membuat sebuah kebijakan dan mengambil perananan yang cukup besar untuk dapat mendorong pencapaian pertumbuhan ekonomi yang lebih maju dengan menaikkan kapasitas produksi masyarakat sehingga pendapatan masyarakat meningkat dan mengurangi jumlah penduduk miskin. Meningkatan pendapatan masyarakat dengan cara, 
menciptakan dan membuka lapangan pekerjaan bagi penduduk setempat), agar lebih baik kedepannya seiring dengan kenaikan penduduk setiap tahunnya.

\section{KESIMPULAN DAN SARAN}

\section{Kesimpulan}

Perkembangan pendapatan perkapita di provinsi-provinsi se-Sumatera selama tahun 2010 sampai tahun 2017 mengalami perkembangan yang cenderung meningkat dengan rata-rata perkembangan tertinggi tercatat di Provinsi Bengkulu yaitu sebesar 9,48 persen sementara perkembangan belanja modal dan tingkat kemiskinan pada wilayah dan tahun yang sama mengalami perkembangan yang berfluktuasi dengan rata-rata perkembangan belanja modal tertinggi tercatat di Provinsi Riau yaitu sebesar 32,96 persen dan tingkat kemiskinan terjadi di Sumatera Barat dengan penurunan tertinggi sebesar $-4,54$ persen. Pengaruh pendapatan perkapita dan belanja modal terhadap tingkat kemiskinan secara bersama-sama berpengaruh signifikan. Sedangkan secara parsial hanya variabel pendapatan perkapita yang berpengaruh signfikan dan negatif terhadap tingkat kemiskinan, sementara belanja modal tidak berpengaruh signifikan dan positif terhadap tingkat kemiskinan.

\section{Saran}

Berdasarkan hasil penelitian dan kesimpulan yang didapat, maka saran yang dapat diberikan oleh peneliti pada penelitian ini, yaitu diharapkan pemerintah daerah provinsi-provinsi di Pulau Sumatera perlu meningkatkan pendapatan perkapita. Salah satu hal yang dapat dilakukan adalah mengadakan program tepat sasaran yang menitik beratkan pada masyarakat miskin. Pemerintah harus menaikkan kapasitas produksi masyarakat sehingga pendapatan masyarakat meningkat dan mengurangi jumlah penduduk miskin serta meningkatan pendapatan masyarakat dengan cara, menciptakan dan membuka lapangan pekerjaan bagi penduduk setempat), agar lebih baik kedepannya seiring dengan kenaikan penduduk setiap tahunnya.

\section{DAFTAR PUSTAKA}

H Basri, S Syaparuddin, J Junaidi. (2013). Pemetaan Kinerja Pendapatan Asli Daerah dan Kemampuan Keuangan Daerah Kabupaten/Kota di Provinsi Jambi, Jurnal Perspektif Pembiayaan dan Pembangunan Daerah, 1 (2), 81-90

Hasan, dan Zikriyah.(2009). Pengaruh belanja modal pemerintah dan produk domestik regional bruto terhadap penduduk miskin di Aceh. Journal SAINS Riset, 1(1) 124136.

Husein, (2008). Metode ramalan kuantitatif untuk perencanaan Ekonomi \& Bisnis. Rineka Cipta : Jakarta.

Nachrowi, dan Hardius Usman. (2006) Pendekatan populer dan praktis ekonometrika untuk analisis ekonomi dan keuangan. lembaga penerbitan Fakultas Ekonomi Universitas Indonesia : Jakarta

Sugiyono, (2013). Metode penelitian kuantitatif kualitatif dan $R \& D$. Alfabeta : Bandung.

Sukirno, Sadono. (2004). Makroekonomi, Teori Pengantar. Rajawali Press : Jakarta.

Sukirno,Sadono. (2006). Ekonomi pembangunan, Jakarta : Kencana

Sulistyaningsih, (2011). Metodologi penelitian kuwantitatif. Graha Ilmu : Yogyakarta. 
Syaiful, (2008). Pengertian dan Perlakuan Akuntansi Belanja Barang dan Pendapatan perkapita dalam Kaidah Akuntansi Pemerintahan : Jakarta

VT Vanesha, S Rahmadi, P Parmadi. (2019).Pengaruh pendapatan asli daerah, dana alokasi umum dan dana alokasi khusus terhadap belanja modal pada kabupaten/kota di Provinsi Jambi, Jurnal Paradigma Ekonomika, 14 (1), 27-36

Wibisono, (2005). Metode penelitian \& analisis data. Salemba Medika.

Widarjono, Agus. (2009). Ekonometrika pengantar dan aplikasinya. Ekonisia: Yogyakarta. 